\title{
ANALISIS PRODUK WISATA SITUS BAWAH AIR SEBAGAI SALAH SATU WISATA MINAT KHUSUS DI TAMAN NASIONAL KARIMUNJAWA
}

\author{
Adyanti Putri Ariadi \\ Magister Arsitektur Pariwisata, Fakultas Teknik, Universitas Gadjah Mada \\ adyanti.putri@gmail.com
}

Budi Prayitno

Jurusan Teknik Arsitektur dan Perencanaan, Fakultas Teknik, Universitas Gadjah Mada

budi.prayitno@ugm.ac.id

Dimas Wihardyanto

Jurusan Teknik Arsitektur dan Perencanaan, Fakultas Teknik, Universitas Gadjah Mada wihardyanto@gmail.com

\begin{abstract}
Abstrak
Kepulauan Karimunjawa merupakan salah satu Kawasan Strategis Pariwisata Nasional (KSPN) di Indonesia yang sedang dikembangkan. Keunggulan dari pariwisata di Karimunjawa adalah daya tarik wisata alamnya yang berupa wisata bahari, ekowisata, dan wisata petualangan. Potensi kekayaan bahari di Karimunjawa yang tidak kalah menarik salah satunya berupa peninggalan budaya bawah air. Tempat tenggelamnya kapal dan peninggalan bawah air yang berada di Karimunjawa membuat situs-situs ini berpotensi menjadi alternatif tujuan wisata bawah air khususnya daya tarik wisata minat khusus. Tujuan dari penelitian ini adalah menjelaskan profil produk wisata situs-situs bawah air di Karimunjawa. Secara administratif penelitian ini akan difokuskan berdasarkan batas geografis dari situs-situs bawah air yang berada di Perairan Pulau Karimunjawa (Situs Kapal Genteng dan Kapal Indonoor) dan Perairan Pulau Genting (Situs Seruni dan Situs Genting). Penelitian ini akan mengunakan metode deskriptif kualitatif. Pengamatan fisik akan dilakukan pada produk wisata (atraksi, aksesibilitas, akomodasi, fasilitas, service) serta lingkungan pada kawasan situs-situs peninggalan bawah air. Hasil penelitian menunjukkan bahwa situs-situs bawah air di Perairan Karimunjawa yang dapat dikembangkan sebagai daya tarik wisata minat khusus adalah Situs Kapal Indonoor dan Situs Kapal Genteng. Sedangkan untuk Situs Seruni dan Situs Genting masih harus dilakukan studi lebih lanjut karena dengan kondisi produk wisata saat ini kedua situs tersebut belum memungkinkan untuk dijadikan obyek wisata minat khusus.
\end{abstract}

Kata-Kata Kunci: produk wisata, wisata minat khusus, situs bawah air, Karimunjawa

\section{ANALYSIS OF TOURISM PRODUCTS OF UNDERWATER SITES AS ONE OF SPECIAL INTEREST TOURISM IN KARIMUNJAWA NATIONAL PARK}

\begin{abstract}
Karimunjawa Islands are one of the National Tourism Strategic Areas in Indonesia and development of these areas are already underway. Sinking ships and underwater heritage in Karimunjawa make the sites in these areas a potential alternative to underwater tourist destinations, especially for special interest tourism. The purpose of this research is to explain the profile of tourism products underwater sites in Karimunjawa. The research focus was divided based on the geographical boundaries of the underwater sites in the waters of Karimunjawa Island (Genteng and Indonoor Shipwreck Sites) and the waters of Genting Island (Seruni and Genting Sites). This
\end{abstract}


research used a qualitative descriptive method grounded in relevant theories. The physical observation was made on tourism products (attractions, accessibility, accommodation, facilities, and service) and the environment around the sites of underwater relics. Findings of the research suggest that underwater sites which are potential for development as special interest tourism objects are Genteng and Indonoor Shipwreck Sites. As for Seruni and Genting Sites, further research needs to be undertaken because considering the current condition of the tourism products; it does not seem feasible to make both of these sites special interest tourism objects

Keywords: tourism products, special interest tourism, underwater sites, Karimunjawa

\section{Pendahuluan}

Indonesia merupakan negara yang memiliki kekayaan peninggalan budaya bawah air berupa kapal karam beserta muatan berharganya dari abad ke-4 sampai dengan perang dunia ke-2 (Indrayono dalam Adhityatama; 2012). Sejak ratusan tahun lalu Indonesia banyak dilalui kapal dari berbagai bangsa. Kapal-kapal tersebut berlayar dengan tujuan antara lain berdagang, berkomunikasi, dan bermigrasi. Dalam pelayaran tersebut tidak semuanya berjalan dengan lancar, terkadang banyak faktor yang menghambat, seperti perampokan dan cuaca buruk, sehingga kapal menjadi karam. Melimpahnya tinggalan kapal tenggelam di kawasan perairan Nusantara dari masa kolonial ditunjukkan dengan setidaknya ada 463 kapal tenggelam yang tercatat berada di perairan Indonesia saat ini. Dari jumlah tersebut baru sekitar $10 \%$ yang diketahui posisinya. Potensi kekayaan bahari berupa peninggalan budaya bawah air tersebut dapat dijadikan objek wisata yang menarik untuk dikunjungi para wisatawan. Selain dapat dimanfaatkan untuk pengembangan ilmu pengetahuan, dengan pengelolaan yang tepat sangatlah mungkin Indonesia menjadi tujuan utama wisata bahari (wisata selam, snorkeling) dan wisata minat khusus. Namun pemanfaatan terhadap situs bawah air ini perlu dilakukan dengan hati-hati karena sifatnya yang tidak dapat diperbaharui (non renewable resources) dan sangat rapuh terhadap ancaman dari luar baik karena kondisi alam maupun aktivitas manusia.

Salah satu kawasan yang memiliki potensi situs peninggalan bawah air yang cukup menarik adalah Kepulauan Karimunjawa. Banyaknya peninggalan budaya di Kepulauan Karimunjawa disebabkan oleh posisi strategis kawasan tersebut yang berada di tengah - tengah jalur pelayaran dan perdagangan Laut Jawa. Karimunjawa selalu menjadi pelabuhan transit pada 3 masa penting dalam sejarah Indonesia, yaitu (1) pada masa kerajaan-kerajaan kuno dengan pelabuhan utama Tuban, (2) masa Kesultanan Islam dengan pelabuhan utama Jepara, dan (3) masa Kolonialisme Eropa dengan pelabuhan utama Semarang (Balai Arkeologi Yogyakarta, 2009).

Tempat tenggelamnya kapal dan peninggalan bawah air yang berada di daerah wisata bahari Karimunjawa membuat situs-situs ini berpotensi menjadi alternatif tujuan wisata bawah air di perairan tersebut. Penyelaman yang ada tidak hanya untuk wisata, beberapa peneliti dan agen sertifikasi selam memanfaatkan situs ini sebagai tempat penyelaman. Di Indonesia saat ini situs peninggalan bawah air belum menjadi suatu daya tarik utama dalam wisata, apabila dibandingkan dengan daya tarik alam Indonesia yang memang dikenal keindahan dan keanekaragaman hayatinya. Kondisi pariwisata di Kepulauan Karimunjawa kini semakin berkembang, akan tetapi situs bawah air di Perairan Karimunjawa belum menjadi daya tarik utama serta belum banyak berperan dalam kegiatan pariwisata di Karimunjawa. Meskipun telah banyak wisatawan yang datang berkunjung untuk melihat keindahan keanekaragaman hayati Taman Nasional Karimunjawa seperti melihat ikan dan terumbu karang, namun pengelolaannya dirasa belum optimal. Tujuan dari penelitian ini adalah mendeskripsikan dan menjelaskan profil produk wisata situs-situs bawah air di Karimunjawa, khususnya di Perairan Pulau Karimunjawa dan Pulau Genting. 


\section{Potensi Wisata Situs Bawah Air di Perairan Pulau Karimunjawa dan Pulau Genting}

1. Situs Kapal Genteng / Kapal "Nusa Indah"

Situs ini berupa kapal kayu yang tenggelam dalam perjalanan dari Madura ke Kalimantan. Terletak di Perairan Pulau Karimunjawa tepatnya di Perairan Pulau Menjangan pada kedalaman 28$30 \mathrm{~m}$. Untuk mencapai situs ini, diperlukan waktu sekitar 25 menit dari Dermaga Syahbandar dengan menggunakan perahu nelayan/speedboat. Situs Kapal Genteng ini memiliki muatan berupa bahan pangan, sandang, dan bahan bangunan. Kapal tersebut tenggelam karena ada kerusakan (kebocoran) akibat terkena terjangan gelombang besar. Situs kapal karam ini dikenal oleh masyarakat dengan nama Kapal Genteng karena banyaknya temuan muatan genteng yang berserakan di sekitar kapal tersebut.

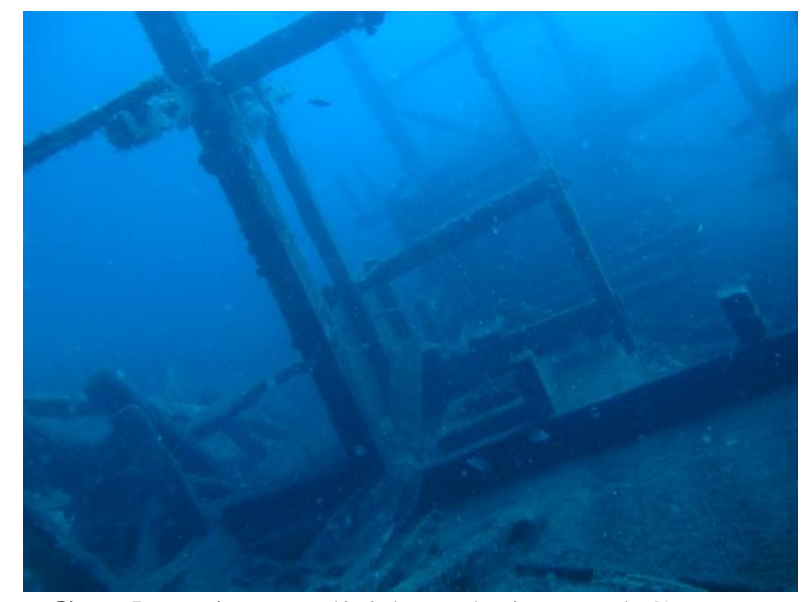

Gambar 1. Kondisi bangkai Kapal Genteng

Sumber: Dokumentasi Ramadhan, 2011

\section{Situs Kapal Indonoor}

Situs Kapal Indonoor ini merupakan situs kapal karam yang paling banyak dikunjungi oleh wisatawan. Selain karena menarik dan menantang, kedalaman situs ini hanya sekitar $15 \mathrm{~m}$ sehingga bisa diselami oleh penyelam mulai dari pemula sampai dengan yang sudah ahli. Untuk mencapai situs ini, diperlukan waktu sekitar 70 menit dari Dermaga Syahbandar dengan menggunakan perahu nelayan/speedboat. Menurut informasi masyarakat lokal, kapal ini tersangkut di terumbu karang dan mengalami kebocoran, dimungkinkan karena gaya berat kapal menyebabkan kapal patah pada beberapa bagian. Tidak ada korban dalam peristiwa ini. Saat ini kapal tersebut hanya tersisa lempengan-lempengan baja hasil penghancuran bom dari beberapa usaha pengangkatan.

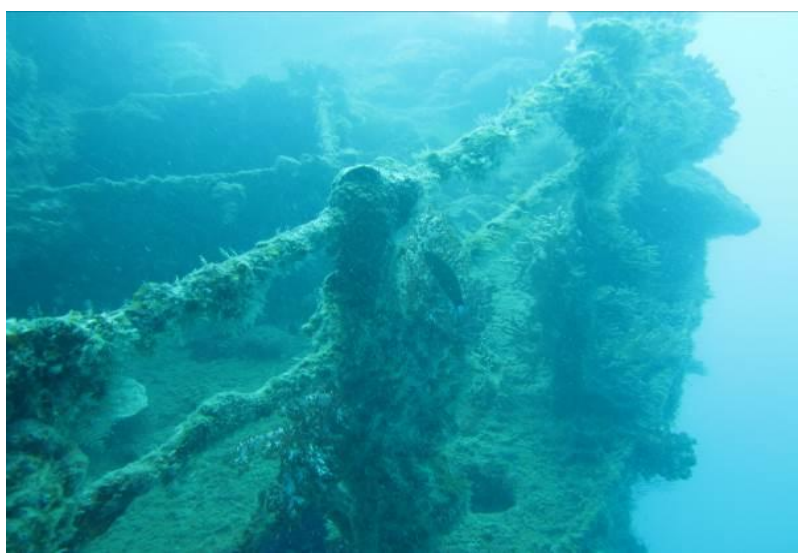

Gambar 2. Kondisi bangkai Kapal Indonoor

Sumber: Dokumentasi Ramadhan, 2011 


\section{Situs Seruni}

Situs Seruni merupakan situs bangkai kapal kayu yang berada di sebelah tenggara Pulau Seruni. Selain karena kedalaman situs ini yang hanya sekitar 8-13 m, posisinya yang terlindung oleh gosong Pulau Seruni di sebelah selatannya juga membuat kondisi perairan di sekitar bangkai kapal sangat tenang, terlindung oleh pengaruh arus dari laut lepas dari sebelah selatan, sehingga aman untuk kegiatan penyelaman. Untuk mencapai situs ini, diperlukan waktu sekitar 2 jam dari Dermaga Syahbandar dengan menggunakan perahu nelayan/speedboat. Menurut informasi dari masyarakat lokal, bangkai kapal tersebut karam sekitar 18 tahun yang lalu. Kondisi bangkai kapal yang masih dapat diamati saat ini adalah beberapa gading dan bagian haluan kapal.

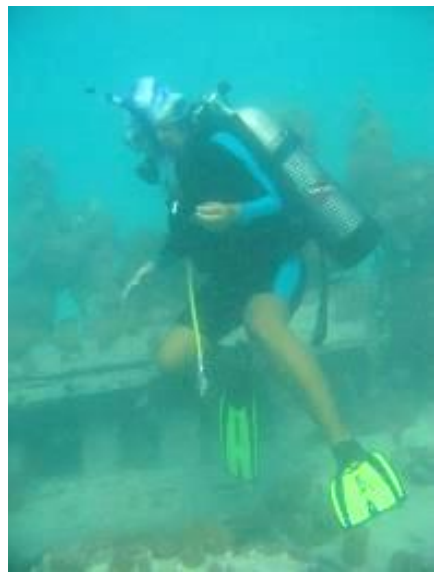

Gambar 3. Penyelaman di sisa-sisa kayu kapal Situs Seruni Sumber: Dokumentasi Balai Arkeologi Yogyakarta, 2009

\section{Situs Genting}

Situs Genting berbeda dengan 3 situs sebelumnya yang merupakan bangkai kapal. Pada situs ini tidak ditemukan sisa-sisa kapal tenggelam, tetapi hanya berupa sebaran fragmen keramik yang diduga keramik-keramik kuno. Dengan kedalaman yang hanya $2 \mathrm{~m}$, untuk melihat situs ini bisa dilakukan dengan snorkeling saja, tidak diperlukan penyelaman. Sebaran fragmen keramik kuno ini terletak di area gosong sebelah timur Pulau Genting, tersebar pada radius $150 \mathrm{~m}$. Untuk mencapai situs ini, diperlukan waktu sekitar 2 jam dari Dermaga Syahbandar dengan menggunakan perahu nelayan/speedboat. Sebaran keramik di gosong Pulau Genting juga merupakan bukti bahwa Pulau tersebut merupakan bagian penting dalam dunia pelayaran perdagangan masa lalu. 


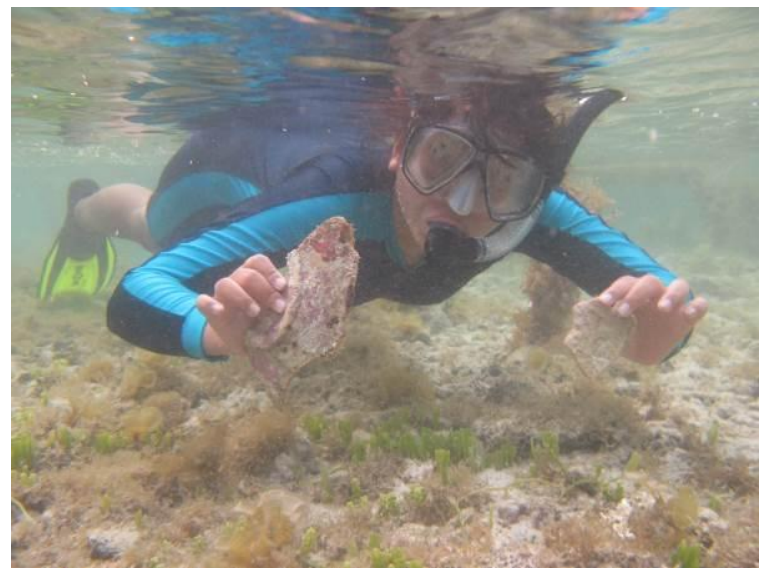

Gambar 4. Keramik kuno yang ditemukan di Situs Genting Sumber: Dokumentasi Balai Arkeologi, 2009

\section{Kajian Pustaka}

Produk wisata secara umum terbentuk disebabkan oleh tiga komponen utama yaitu atraksi wisata, amenitas atau fasilitas di daerah tujuan wisata, dan aksesibilitas. Atraksi wisata merupakan salah satu komponen penting dalam pariwisata dan juga menjadi salah satu faktor inti tarikan pergerakan wisatawan menuju daerah tujuan wisata. Terdapat dua fungsi dari atraksi yaitu sebagai stimulan atau umpan pariwisata serta sebagai salah satu produk utama pariwisata dan faktor tujuan utama kedatangan pengunjung. Atraksi wisata yang baik harus dapat mendatangkan wisatawan sebanyak-banyaknya, menahan mereka di tempat atraksi dalam waktu yang cukup lama dan memberi kepuasan kepada wisatawan yang datang berkunjung. Untuk mencapai hasil itu, beberapa syarat harus dipenuhi, yaitu (Yoeti dalam Rahmat, 2015) :

1. Kegiatan (act) dan obyek (artifact) yang merupakan atraksi harus dalam keadaan baik

2. Karena atraksi wisata itu harus disajikan di hadapan wisatawan maka cara penyajiannya (presentasinya) harus tepat

3. Atraksi wisata merupakan terminal suatu mobilitas spasial, suatu perjalanan. Oleh karena itu juga harus memenuhi semua determinan mobilitas spasial, yaitu akomodasi, transportasi, promosi serta pemasaran

4. Keadaan di tempat atraksi harus dapat menahan wisatawan cukup lama

5. Kesan yang diperoleh wisatawan waktu menyaksikan atraksi wisata harus diusahakan supaya bertahan selama mungkin

Eksistensi situs-situs peninggalan bawah air di Karimunjawa ini tidak lepas dari prinsip pelestarian yang merujuk pada Undang Undang Cagar Budaya No.11 tahun 2010. Pelestarian yang dimaksud harus mampu melaksanakan program perlindungan, pengembangan, dan pemanfaatan secara terpadu dan berkelanjutan. Pelestarian tidak hanya mengarah pada perlindungan, melainkan juga pemanfaatan sumber daya untuk kesejahteraan masyarakat lokal pada khususnya dan wisatawan pada umumnya (Tanudirdjo, 2010). Terdapat beberapa jenis pemanfaatan, misalnya untuk kepentingan pendidikan, kebudayaan, sejarah, pariwisata, sosial, dan agama. Secara khusus jenis pemanfaatan mencakup 3 kategori, yaitu pemanfaatan untuk pendidikan dan kebudayaan, penelitian, dan ekonomi. Pariwisata termasuk dalam kategori pemanfaatan ekonomi secara tidak langsung, yaitu segala upaya pemanfaatan BCB yang dilakukan dalam bentuk jasa sehingga nilai ekonominya baru akan diperoleh sesudah $\mathrm{BCB}$, situs, atau kawasan dikelola lebih dahulu sehingga dapat memberikan daya tarik untuk dikunjungi. 


\section{Metode Penelitian}

Penelitian ini mengunakan metode deskriptif kualitatif yang berdasarkan teori-teori terkait. Unit analisis muncul dari tanggapan masyarakat yang berupa hasil pengisian kuesioner dan wawancara dengan pemerintah serta masyarakat, kemudian di cross check untuk membuktikan validitasnya. Analisis ini mendeskripsikan secara terperinci dan menyeluruh terhadap pandangan atau tanggapan yang diperoleh, kemudian dijadikan dasar dalam pengembangan wisata situs bawah air sebagai wisata minat khusus di Kepulauan Karimunjawa khususnya di Perairan Pulau Karimunjawa dan Pulau Genting. Analisis akan dilakukan terhadap data yang telah dikumpulkan dengan tujuan untuk mendeskripsikan data yang ada, sehingga data-data yang ada mudah dipahami dan diinterpretasikan. Sesuai dengan latar belakang, maka analisis akan dilakukan terhadap faktorfaktor yang berpengaruh terhadap penilaian potensi serta minat wisatawan terhadap obyek situs peninggalan bawah air di Perairan Pulau Karimunjawa dan Pulau Genting sebagai wisata minat khusus.

Tahap analisis dilakukan dengan cara menganalisis data yang terkumpul dengan melakukan analisis produk dan analisis minat wisatawan berdasarkan kondisi eksisting produk wisata terhadap pengembangan situs bawah air sebagai daya tarik wisata minat khusus. Berikut merupakan diagram urutan langkah-langkah analisis yang akan dilakukan:

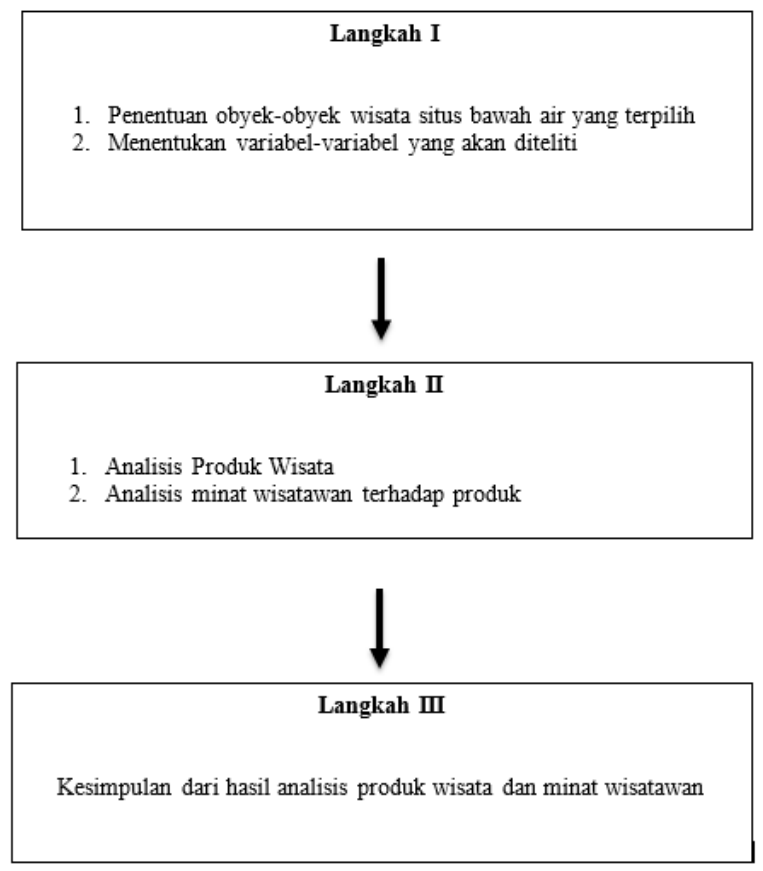

Gambar 5. Diagram urutan analisis yang akan dilakukan Sumber: Tahapan analisis oleh Penulis, 2018

\section{Hasil dan Pembahasan Analisis Produk}

Analisis produk dilakukan dengan melakukan perhitungan prosentase hasil survei dengan hasil pembobotan ahli. Hasil dari perhitungan tersebut bertujuan untuk melihat apa yang mempengaruhi wisatawan dalam melakukan suatu kunjungan wisata, terlihat dari tinggi-rendahnya nilai dari variabel dan indikator produk 
Tabel 1. Hasil Analisis Produk

\begin{tabular}{|c|c|c|}
\hline $\begin{array}{l}\text { Variabel } \\
\text { Parameter }\end{array}$ & $\begin{array}{l}\text { Indikator dan Hasil } \\
\text { Pembobotan Ahli }\end{array}$ & $\begin{array}{c}\text { Hasil penghitungan dari pembobotan ahli \& } \\
\text { survei lapangan }\end{array}$ \\
\hline \multirow{3}{*}{ Atraksi } & Daya Tarik (59\%) & $\begin{array}{l}\text { Daya tarik memiliki nilai positif } 77,6 \% \text { dari } \\
\text { variabel atraksi }\end{array}$ \\
\hline & Variasi $(18 \%)$ & $\begin{array}{l}\text { Variasi memiliki nilai positif } 58,4 \% \text { dari variabel } \\
\text { atraksi }\end{array}$ \\
\hline & Kesan Wisatawan (23\%) & $\begin{array}{l}\text { Kesan / citra wisatawan memiliki nilai positif } 61 \% \\
\text { dari variabel atraksi }\end{array}$ \\
\hline \multirow{3}{*}{ Aksesibilitas } & $\begin{array}{l}\text { Ketersediaan Sarana } \\
\text { Transportasi }(25 \%)\end{array}$ & $\begin{array}{l}\text { Ketersediaan sarana transportasi memiliki nilai } \\
\text { positif } 51 \% \text { dari variabel aksesibilitas }\end{array}$ \\
\hline & $\begin{array}{l}\text { Ketersediaan Sarana } \\
\text { Informasi }(46 \%)\end{array}$ & $\begin{array}{l}\text { Ketersediaan sarana informasi memiliki nilai positif } \\
56 \% \text { dari variabel aksesibilitas }\end{array}$ \\
\hline & $\begin{array}{l}\text { Kenyamanan \& Keamanan } \\
(31 \%)\end{array}$ & $\begin{array}{l}\text { Keamanan dan kenyamanan memiliki nilai positif } \\
54 \% \text { dari variabel aksesibilitas }\end{array}$ \\
\hline \multirow{4}{*}{ Amenitas } & Kualitas \& Pelayanan (40\%) & $\begin{array}{l}\text { Kualitas dan pelayanan memiliki nilai positif } 68 \% \\
\text { dari variabel amenitas }\end{array}$ \\
\hline & $\begin{array}{l}\text { Ketersediaan Fasilitas } \\
\text { Pendukung }(24 \%)\end{array}$ & $\begin{array}{l}\text { Ketersediaan fasilitas - fasilitas pendukung } \\
\text { memiliki nilai positif } 49 \% \text { dari variabel amenitas }\end{array}$ \\
\hline & Kebersihan $(20 \%)$ & $\begin{array}{l}\text { Kebersihan memiliki nilai positif } 52 \% \text { dari } \\
\text { variabel amenitas }\end{array}$ \\
\hline & $\begin{array}{l}\text { Akses menuju Fasilitas } \\
(16 \%)\end{array}$ & $\begin{array}{l}\text { Kemudahan akses menuju fasilitas memiliki nilai } \\
\text { positif } 48 \% \text { dari variabel amenitas }\end{array}$ \\
\hline
\end{tabular}
Sumber: Analisis Penulis, 2017

\section{A. Atraksi}

Komponen produk atraksi yang berupa situs-situs bawah air ini memberikan daya tarik wisata bawah air baru di Karimunjawa. Atraksi yang ditawarkan berupa 4 situs bawah air di Perairan Pulau Karimunjawa dan Pulau Genting yaitu Situs Kapal Indonoor, Situs Kapal Genteng, Situs Seruni, dan Situs Genting. Hingga saat ini situs bawah air yang paling sering dikunjungi oleh wisatawan adalah Situs Kapal Indonoor. Akan tetapi untuk mengunjungi Situs Kapal Indonoor ini hanya bisa dengan menyelam (diving) saja, wisatawan yang ingin mengunjungi situs ini harus memiliki sertifikasi selam dan didampingi oleh pemandu selam, sehingga tidak semua kalangan wisatawan dapat mengunjungi Situs Indonoor ini.

Dari hasil perhitungan pembobotan ahli dengan survei responden wisatawan, daya tarik wisata merupakan indikator dalam variabel atraksi yang paling mempengaruhi wisatawan untuk berkunjung ke situs-situs bawah air di Perairan Pulau Karimunjawa dan Pulau Genting. Situssitus ini juga dapat menambah variasi wisata dan berpotensi untuk dikembangkan sebagai wisata bawah air baru di Kepulauan Karimunjawa.

\section{B. Aksesibilitas}

Dari hasil perhitungan pembobotan ahli dengan survei responden wisatawan, ketersediaan sarana informasi merupakan indikator dalam variabel aksesibilitas yang paling mempengaruhi wisatawan untuk berkunjung ke Karimunjawa. Dengan adanya transportasi dan kemudahan informasi serta kenyamanan dan keamanan yang didapat, wisatawan yang ingin berkunjung ke Karimunjawa dapat dengan mudah melakukan perjalanan wisata. Mulai dari saat menyeberang ke Pulau Karimunjawa dari Jepara, Semarang, ataupun Kendal; menyeberang ke pulau-pulau kecil dari Dermaga Pelabuhan Karimunjawa; dan saat berada di Pulau Karimunjawa bisa 
berkeliling pulau dengan menggunakan kendaraan bermotor roda 2 atau 4. Aksesibilitas menuju situs-situs bawah air dapat ditempuh dengan menggunakan kapal nelayan dari Dermaga Pelabuhan Karimunjawa. Hingga saat ini aksesibilitas menuju Situs Kapal Indonoor dan Kapal Genteng yang paling sering digunakan oleh wisatawan karena jaraknya yang tidak terlalu jauh dari dermaga. Untuk aksesibilitas menuju Situs Seruni dan Situs Genting cukup sulit karena membutuhkan waktu sekitar 4 jam perjalanan pulang pergi serta membutuhkan biaya yang tidak sedikit.

\section{Amenitas}

Dari hasil perhitungan pembobotan ahli dengan survei responden wisatawan, kualitas dan pelayanan merupakan indikator dalam variabel amenitas yang paling mempengaruhi wisatawan untuk berkunjung ke Karimunjawa. Meningkatnya jumlah kunjungan wisatawan baik wisatawan domestik maupun mancanegara ke Taman Nasional Karimunjawa membuat warga sekitar semakin menjaga kualitas serta pelayanan yang diberikan. Mulai dari penginapan serta fasilitas-fasilitas pendukung seperti rumah makan, pusat souvenir, pusat informasi wisata, dan dive center. Berdasarkan hasil survei responden wisatawan, homestay menjadi pilihan mereka menginap saat berkunjung ke Karimunjawa. Selain karena harganya yang cukup terjangkau, tingkat kebersihan, kesehatan, keamanan, dan kenyamanannya juga sudah memberikan kepuasan pada wisatawan.

Amenitas yang lengkap saat ini hanya didapatkan di Pulau Karimunjawa, bersama dengan pusat pemerintahannya. Untuk pulau-pulau kecil yang berpenghuni yaitu Pulau Nyamuk, Pulau Genting, dan Pulau Parang belum memiliki amenitas yang lengkap. Wisatawan yang ingin mengunjungi situs-situs bawah air yang berada di Pulau Genting yaitu Situs Seruni dan Situs Genting akan mengalami kesulitan jika ingin menginap di Pulau Genting karena belum ada penginapan serta fasilitas-fasilitas pendukung seperti di Pulau Karimunjawa

\section{Analisis Minat Wisatawan}

Tabel 2. Hasil Analisis Minat Wisatawan

\begin{tabular}{ll} 
Variabel Parameter & \multicolumn{1}{c}{ Indikator } \\
& $\begin{array}{l}\text { Frekuensi kunjungan wisatawan ke Karimunjawa sebagian besar } \\
\text { merupakan repeater (lebih dari 2x kunjungan) }\end{array}$ \\
& $\begin{array}{l}\text { Motivasi wisatawan yang berkunjung ke Karimunjawa adalah untuk } \\
\text { rekreasi (melihat keindahan biota laut) }\end{array}$ \\
\hline Psikografis & $\begin{array}{l}\text { Aktivitas yang dilakukan wisatawan saat berkunjung ke } \\
\text { Karimunjawa adalah diving dan snorkeling }\end{array}$ \\
\hline & $\begin{array}{l}\text { Wisatawan tertarik untuk mengunjungi situs-situs bawah air di } \\
\text { Perairan Pulau Karimunjawa dan Pulau Genting karena memberikan } \\
\text { kepuasan tersendiri }\end{array}$ \\
&
\end{tabular}

Sumber: Analisis Penulis, 2017

Dari hasil survei responden wisatawan tentang minat berwisata ke Karimunjawa, diketahui bahwa sebagian besar wisatawan sudah pernah berkunjung ke Karimunjawa sebelumnya (repeater). Motivasi berkunjung adalah untuk rekreasi, diving/snorkeling melihat keindahan biota laut bawah air. Melihat foto situs-situs bawah air yang ditampilkan pada lembar kuesioner, wisatawan tertarik untuk mengunjungi situs-situs tersebut karena penasaran, unik, serta memberikan tantangan dan kepuasan tersendiri 


\section{Kesimpulan}

Berdasarkan hasil analisis diketahui bahwa situs bawah air yang dikembangkan sebagai obyek pariwisata khususnya wisata minat khusus yaitu Situs Kapal Indonoor dan Situs Kapal Genteng yang berada di Perairan Pulau Karimunjawa. Kedua situs tersebut merupakan situs yang sering dikunjungi oleh wisatawan dan juga telah mendapat perhatian dari pemerintah serta masyarakat pelaku pariwisata di Karimunjawa. Selain karena jarak tempuhnya yang cukup mudah dijangkau, kedalaman kedua situs tersebut memungkinkan untuk dikunjungi para wisatawan dengan melakukan penyelaman. Kegiatan penyelaman dapat dilakukan mulai dari penyelam pemula dengan didampingi dive guide, sampai dengan penyelam ahli. Untuk saat ini situs-situs yang berada di Perairan Pulau Genting yaitu Situs Seruni dan Situs Genting belum bisa menjadi daya tarik wisata minat khusus. Selain karena lokasinya yang jauh; ombak dan angin timur yang kurang bersahabat; serta kurangnya informasi, kedua situs ini dekat dengan Pulau Gundul yang merupakan lokasi latihan tembak Angkatan Laut sehingga kurang aman dan nyaman bagi wisatawan untuk berkunjung ke sana. Diperlukan studi yang lebih mendalam apabila kedua situs ini akan dijadikan obyek wisata minat khusus. Berdasarkan hasil wawancara dengan narasumber, pemerintah lebih mengembangkan wisata situs bawah air ke arah barat Kepulauan Karimunjawa yaitu ke arah Pulau Parang dan Pulau Nyamuk. Banyak situs bawah air yang menarik dan berpotensi untuk dijadikan obyek wisata minat khusus di perairan sebelah barat Kepulauan Karimunjawa.

Berdasarkan hasil analisis, dapat dilihat tiga indikator dari variabel produk wisata yang berpengaruh terhadap minat wisatawan untuk berkunjung ke situs bawah air di Perairan Karimunjawa adalah sebagai berikut:

\section{Daya Tarik}

Hasil analisis menunjukkan bahwa diantara semua indikator variabel atraksi, daya tarik merupakan indikator yang paling mempengaruhi wisatawan untuk berkunjung ke obyek wisata situs bawah air. Daya tarik memiliki nilai positif sebesar 77,6 \% dari variabel atraksi. Dalam hal ini atraksi yang berupa situs-situs bawah air di Perairan Karimunjawa yang menjadi daya tarik utama bagi wisatawan.

\section{Ketersediaan Informasi}

Hasil analisis juga menunjukkan bahwa diantara semua indikator variabel aksesibilitas, ketersediaan informasi merupakan indikator yang paling mempengaruhi pertimbangan wisatawan untuk berkunjung ke situs bawah air. Ketersediaan informasi ini memiliki nilai positif sebesar $56 \%$ dari semua variabel aksesibilitas. Informasi yang dimaksud termasuk dalam indikator variabel aksesibilitas yaitu informasi tentang jadwal kapal, harga, dan waktu tempuh. Dengan adanya kemudahan informasi yang didapat, wisatawan merasa aman dan nyaman dalam melakukan perjalanan wisata.

\section{Kualitas dan Pelayanan Fasilitas}

Hasil analisis menunjukkan bahwa diantara semua indikator variabel amenitas, kualitas dan pelayanan fasilitas seperti penginapan, rumah makan, pusat informasi wisata, pusat souvenir, dive center, menjadi indikator yang paling mempengaruhi wisatawan untuk berkunjung ke situs bawah air di Karimunjawa. Indikator kualitas dan pelayanan fasilitas ini memiliki nilai positif sebesar $68 \%$ dari semua variabel amenitas. Semakin baik kualitas dan pelayanan dari suatu amenitas, semakin nyaman pula wisatawan untuk berwisata 


\section{Daftar Pustaka}

Adhityatama, S. (2012) Pemodelan Jalur Aktivitas Penyelaman Di Situs USAT Liberty, Tulamben, Bali : Studi Pengelolaan Sumberdaya Arkeologi. Skripsi Sarjana. Departemen Arkeologi Fakultas Ilmu Budaya Universitas Gadjah Mada. Yogyakarta.

Anonim. (2006). Pedoman Pengelolaan Peninggalan Bawah Air. Direktorat Peninggalan Bawah Air. Jakarta.

Dillenia, I, et.al. (2010). Sumberdaya Arkeologi Laut Untuk Pengembangan Ekowisata Bahari di Indonesia : Tinjauan Konsep dan Studi Kasus. Pertemuan Ilmiah Tahunan VI ISOI 2009. Jakarta.

Helmi, S. (2009). Potensi Peninggalan Arkeologi Bawah Air di Perairan Pulau Sumatera. Buletin Arkeologi Amoghapasa Edisi 13 Thn. XV/Juni 2009. Balai Pelestarian Peninggalan Purbakala (BP3). Batusangkar.

Jaksic, S, et.al. (2013). Impacts of Artificial Reefs and Diving Tourism. Turizam Journal Vol. 7, Issue 4, 155-165. Department of Geography, Tourism, and Hotel Management, Faculty of Science, University of Novi Sad. Serbia.
Laporan Penelitian Arkeologi. (2009). Melacak Budaya Bahari di Kepulauan Karimunjawa Tahap II. Balai Arkeologi Yogyakarta. Yogyakarta.

Noviandra, G, P. (2014). Strategi Pelestarian Situs Kapal Tenggelam Indonor di Kepulauan Karimunjawa. Skripsi Sarjana. Departemen Arkeologi Fakultas Ilmu Budaya Universitas Gadjah Mada. Yogyakarta.

Rahmat, K, D. (2015). Potensi Aktivitas Arkeologi Sebagai Daya Tarik Wisata Minat Khusus Untuk Meningkatkan Kualitas Pengalaman Wisatawan di Kawasan Prambanan. Tesis, MPAR, Universitas Gadjah Mada : Yogyakarta.

Ramadhan, Ahmad Surya. (2011). Dokumentasi Pribadi. Yogyakarta.

Tanudirjo, D, A. (2001). Wisata Arkeologi, antara Ilmu dan Hiburan. Jurnal Penelitian "Memediasi Masa Lalu : Spektrum Arkeologi dan Pariwisata". Lephasi. Makassar.

Yoeti, O, A. (1997). Perencanaan dan Pengembangan Pariwisata. Pradnya Paramita : Jakarta.

Yussubrasta, D, et.al. (2012). Himpunan Data Cagar Budaya Bawah Air Indonesia. Direktorat Pelestarian Cagar Budaya dan Permuseuman. Jakarta. 